\title{
Hemmafru eller gymnastikdirektör eller både och? Kvinnliga gymnastikdirektörer, GCI och folkhemmet 1932-1952
}

\begin{abstract}
Leif Yttergren
Abstract • Housewife or Physical Education Teacher? Or Both? Female Physical Education Teachers and the Welfare State, 1932-1952 - The purpose of the article is to analyse the occupational careers and lifestyles of 32 female physical education teachers during the period 1932-1973. The results show that women could work both as physiotherapists and as physical education teachers. Many chose the former, which in Central Institute of Gymnastics' (Gymnastiska centralinstitutet, GCI) own historical writing has been reduced in favor of the physical education teachers. The women came from the middle or upper middle class of society. They were around 20 years old when they started the two-year education at GCI, which attracted students from all over the country. They could combine marriage and children with work, even though it meant duplication and difficulty in bringing together the socalled "life puzzle." Unlike many other women at this time, the physical education teachers chose the occupational career instead of becoming full time housewives. Their attitude can be explained by the occupational and caring character of the profession, but also with the strong loyalty that existed in the group and the GCI-spirit.
\end{abstract}

Keywords • female physical education teachers [kvinnliga gymnastikdirektörer], careers [karriärer], marriages [äktenskap], life stories [livshistorier]

\section{Inledning}

Försommaren 1932 utexaminerades $32^{1}$ unga kvinnor från Gymnastiska centralinstitutet (GCI) i Stockholm. De hade genomgått en för tiden eftertraktad professionsutbildning och erhöll efter examen titeln gymnastikdirektör. Utbildningen för kvinnor var tvåårig och hade en avgörande fördel i jämförelse med många andra professionsutbildningar. Efter examen kunde nämligen kvinnorna arbeta både som sjukgymnaster, privat och offentligt, och som idrottslärare inom skolväsendet. Dessutom kunde de leda gymnastikföreningar på helger och kvällar för att utöka inkomsten. Chansen att efter examen erhålla ett lönearbete föreföll således goda för de nyexaminerade gymnastikdirektörerna. Samtidigt lämnade kvinnorna GCI i en turbulent tid. 1930-talskrisen pågick med hög arbetslöshet och ekonomisk depression. Paradoxalt nog innebar 1930-talet också en förbättrad reallöneutveckling, att fler

Forskningen har finansierats av Centrum för idrottsforskning och GIH:s Forskar- och forskarutbildningsnämnd till vilka härmed riktas ett stort tack.

1 I vissa GCI-dokument omnämns 34 studenter. Förmodligen var det två studenter som tillhört tidigare årgångar men som av okänd anledning avbröt eller aldrig avslutade sina studier, och som sedan fortsatte sina studier i den undersökta klassen.

Leif Yttergren is Associate Professor of Sports History at The Swedish School of Sport and Health Sciences. Email: leif.yttergren@gih.se 
kvinnor sökte sig till arbetsmarknaden och en förbättrad levnadsstandard generellt för medborgarna. ${ }^{2}$

Syftet med det följande är att analysera kvinnliga gymnastikdirektörers yrkeskarriärer och livsöden under perioden 1932-1973 utifrån ett kollektivbiografiskt perspektiv. I fokus står de kvinnor som gick ut GCI 1932. Frågeställningar: Vilka var kvinnorna som gick ut GCI 1932? Ålder, social tillhörighet, civilstånd och geografisk hemvist? Var och med vad arbetade de efter examen? Hur påverkade ett eventuellt giftermål yrkeskarriären? Vilka likheter och skillnader finns det mellan 1930-talets och 1890-talets gymnastikdirektörs livsöden och yrkeskarriärer? De sistnämnda har analyserats utifrån likartade frågeställningar i flera studier. ${ }^{3}$

Resultaten från dessa studier visar att kvinnorna som gick ut GCI 1893 hade en medelålder på drygt 24 år. En grov geografisk uppdelning efter födelseplats ger vid handen att de antagna kvinnorna kom från hela Sverige och fem från utlandet; det internationella inslaget i klassen var således betydande, 20 procent. När det gäller social tillhörighet visar vår undersökning att kvinnorna framför allt kom från samhällets övre skikt. Vidare framkommer att kvinnorna tvingades göra ett val: antingen yrkeskarriär och barnlöst singelliv eller familj och barn men ingen yrkeskarriär. Totalt gifte sig 13 av 25 efter examen. Formellt sett hade de behörighet att arbeta som både sjukgymnaster och gymnastiklärare, men det var i den privata sfären inom den sjukgymnastiska sektorn som flest arbetsmöjligheter fanns. Arbetsmarknaden för kvinnliga gymnastikdirektörer var också rörlig och till synes oreglerad och sträckte sig utanför landets gränser. Under perioden 1893-1903 åkte 16 av 25 i kursen utomlands för att arbeta som sjukgymnaster. Handlingsutrymmet var därmed stort för de kvinnliga gymnastikdirektörerna.

\section{Forskningsläge}

Syftesbeskrivningen är en aning disparat, vilket gör att forskningsläget omfattar litteratur från skilda områden såsom kvinnohistoria i allmänhet samt utbildnings-och gymnastikhistoria. Kvinnohistorisk forskning som behandlar mellankrigstiden har ett annat fokus än den rika forskningen kring kvinnors livssituation kring sekelskiftet 1900. Då var den kontroversiella rösträttsfrågan central i många studier. Flera forskare har också belyst kvinnors roll i professionaliseringsprocessen vid denna tid, hur vissa yrken maskulinerades och/eller feminiserades. ${ }^{4}$ Den mest relevanta undersökningen för denna studie är historikern Anders Ottossons avhandling Sjukgymnasten - vart tog han vägen? Ottosson menar att sjukgymnastens historia utgör "Sveriges kanske mest intressanta yrkeshistoria, nu helt glömd och utraderad ur det allmänna medvetandet". ${ }^{5}$ Utöver att skriva sjukgymnastikyrkets historia belyser Ot-

2 Hans Nilsson och Lars-Göran Tedebrand, Familjer i växande städer: Strukturer och strategier vid familjebildning i Sverige 1840-1940 (Umeå: Umeå universitet, 2005), 47.

3 Se bland annat Leif Yttergren och Hans Bolling, "Kvinnor, karriär och familj: En studie av svenska kvinnliga gymnastikdirektörers yrkeskarriärer och livsöden kring sekelskiftet 1900," Historisk tidskrift 136, no. 2 (2016).

4 Se t ex Christina Florin, Kampen om katedern: Feminiserings- och professionaliseringsprocessen inom den svenska folkskolans lärarkår 1860-1906 (Umeå: Umeå universitet, 1987); Anders Ottosson, Sjukgymnasten - vart tog han vägen? En undersökning av sjukgymnastyrkets maskulinisering och avmaskulinsering 1813-1934 (Göteborg: Göteborgs universitet, 2007); Lena Sommestad, Från mejerska till mejerist: En studie av mejeriyrkets maskuliniseringsprocess (Lund: Arkiv, 1992).

5 Ottosson (2007), 4. 
tosson "den könsomkodningsprocess som yrket genomgått" under 1900-talet första decennier, det vill säga dess feminisering. ${ }^{6}$

När det gäller kvinnohistorisk forskning som berör mellankrigstiden är det främst kvinnors situation på arbetsmarknaden och i hemmet som behandlats. Kvinnor sökte sig i allt större utsträckning till arbetsmarknaden under denna tid, vilket inte var helt okomplicerat och för många män utmanande. Historiken Ulla Wikander har uttryckt det träffande:

[...] konflikterna mellan könen under mellankrigstiden "flyttade" från en kamp om rättigheter på det statliga området (rösträtten, myndigheten) till en kamp om förvärvsarbete på arbetsmarknaden. ${ }^{7}$

Historikern Yvonne Hirdman menar dock att "husmoderskontraktet" var den handlingsstrategi som vann kampen om kvinnorna under mellankrigstiden och detta med många kvinnors goda minne. Hirdman menar att olika samhällssektorer delades upp mellan könen: männen tog hand om arbets- och politikfältet. Kvinnorna hamnade i hemmet där barnbidrag och ny rationell hushållsteknik bidrog till att en ny mer statusfylld modern husmodersroll växte fram. Konsekvensen av denna sektorsuppdelning mellan könen gav enligt Hirdman upphov till "en modern form av könssegregering".

Det finns också kvinnohistorisk forskning som visar att ett nytt och annat kvinnoideal än husmoderns började slå igenom på 1930-talet, nämligen yrkeskvinnans. Historikern Renée Frangeur framhåller i avhandlingen Yrkeskvinna eller makens tjänarinna:

Forskningen har med andra ord uppfattat kvinnorörelsens aktivister som antingen självständiga politiska aktörer eller objekt för statens eller partiers intressen och som enade eller splittrade efter klass och civilstånd. Mellankrigstidens kvinnoideal har beskrivits som antingen hemmakvinnan eller yrkeskvinnan eller i några fall som bådadera. ${ }^{9}$

Ingen studie har berört de kvinnliga gymnastikdirektörerna under mellankrigstiden utifrån ovan nämnda frågeställningar. I denna studie kommer att visas att mellankrigstidens gymnastikdirektörer kombinerade hemmafrurollen och yrkesrollen och att det fanns en stark identitet och lojalitet med yrkesvalet.

Ett annat relevant forskningsområde för denna studie är gymnastikhistoriskt och utbildningshistoriskt. GCI:s och den svenska (ling)gymnastikens tillkomst och utveckling är väl utforskad, dock med en kraftig koncentration på den pedagogiska (skol)gymnastiken och dess företrädare, vilket lett till en skev bild av GCI och dess studenters utbildning och yrkeskarriärer. ${ }^{10}$ Sjukgymnastikens ställning på GCI var

6 Ottosson (2007), 307.

7 Renée Frangeur, Yrkeskvinna eller makens tjänarinna: Striden om yrkesrätten för gifta kvinnor i mellankrigstidens Sverige (Eslöv: Symposion, 1998), 35.

8 Yvonne Hirdman, "Genusanalys av välfärdsstaten: En utmaning av dikotomierna," i Fra kvinnehistorie til kjönnshistorie, Rapport 3 från det 22. nordiske historikermøde, red. Kari Melby och Kåre Tønnesson (Oslo: IKS, 1994), 75. Se även Frangeur (1998), 31.

9 Frangeur (1998), 31.

10 Om GCI och linggymnastiken, se Hans Bolling och Leif Yttergren, red., 200 år av kroppsbildning: 
betydligt starkare än vad tidigare forskning gjort gällande, vilket Anders Ottossons, Hans Bolling och Leif Yttergren forskning visar. Detta gäller särskilt för de kvinnliga GCI-studenterna, vilka tack vare sjukgymnastiken fick möjlighet till försörjning och i vissa fall till och med egenföretagande. ${ }^{11}$

I sin studie av den danska kvinnogymnastiken visar den danska historikern Anne Lykke Poulsen hur den utvecklades till ett kvinnligt kunskapsfält under 1900-talets första hälft samtidigt som gymnastiklärarna och den kvinnliga gymnastiken professionaliserades. ${ }^{12}$ Lykke Poulsens studie innehåller också ett kollektivbiografiskt kapitel där hon uppmärksammar 166 kvinnliga gymnastiklärare i det danska huvudstadsområdet år 1933. Hennes studie visar att de ur socialt hänseende kom från samhällets övre skikt, vilket också framkommer i Sheila Fletcher's studie av social bakgrund bland kvinnliga idrottslärare i England. ${ }^{13}$ Hans Bollings och Leif Yttergrens resultat angående svenska kvinnliga gymnastikdirektörer, vilka tog examen 1893 från GCI, visar på liknande resultat, möjligen med viss förskjutning mot att dessa kvinnor kom från samhällets toppskikt. ${ }^{14}$

Forskningen har också ägnat kvinnliga gymnastikpionjärer stor uppmärksamhet. Martina Bergman-Österberg, Sally Högström, Elin Falk och Elli Björksten är de mest kända exemplen. ${ }^{15}$ Gemensamt för dessa är dels att alla var verksamma decennierna kring sekelskiftet 1900 och drevs av något som kan liknas vid ett kall för den linggymnastiska saken. Nämnda kvinnor var aktiva inom den pedagogiska gymnastiken. Sjukgymnastiken och dess kvinnliga förgrundsgestalter, och sådana fanns, har inte alls lockat forskningen i samma utsträckning.

Gymnastiska centralinstitutet/Gymnastik- och idrottshögskolan 1813-2013 (Stockholm: GIH, 2013); Barbro Carli, The Making and Breaking of a Female Culture: The History of Swedish Physical Education "in a Different Voice" (Göteborg: Acta Universitatis Gothoburgensis, 2004); Jan Lindroth, Idrottens väg till folkrörelse: Studier i svensk idrottsrörelse till 1915 (Uppsala: Acta Universitatis Upsaliensis, 1974); Jan Lindroth, Gymnastik med lek och idrott: För och mot fria kroppsövningar $i$ det svenska läroverket 1878-1928 (Stockholm: HLS Förlag 1993); Jan Lindroth, Ling - från storhet till upplösning: Studier i svensk gymnastikhistoria 1800-1950 (Stockholm: SISU idrottsböcker, 2004); Jens Ljunggren, Kroppens bildning: Linggymnastikens manlighetsprojekt 1790-1914 (Eslöv: Symposion, 1999); Pia Lundquist Wanneberg, Kroppens medborgarfostran: Kropp, klass och genus i skolans fysiska fostran 1919-1962 (Stockholm: Stockholms universitet, 2004); Suzanne Lundvall och Jane Meckbach, Ett ämne i rörelse: Gymnastik för kvinnor och män i lärarutbildningen vid Gymnastiska centralinstitutet/Gymnastik- och idrottshögskolan under åren 1944 till 1992 (Stockholm: HLS förlag, 2003).

11 Yttergren och Bolling (2016), 204-8.

12 Anne Lykke Poulsen, "Den kvindelige Kvinde:" Kampe om kvindelighed, medborgarskab og professionalisering $i$ dansk kvindegymnastik 1886-1940 (Köpenhamn: Köpenhamns universitet, 2005), 74-83.

13 Poulsen (2005), 77-78; Sheila Fletcher, "The Making and Breaking of a Female Tradition: Women's Physical Education in England 1880-1980," British Journal of Sports History 2, no. 1 (1985), 29-39.

14 Yttergren och Bolling (2016), 198-200.

15 Se t ex Else Trangbaek, "Sally Högström og det moderne kvindeprojekt - Svensk gymnastik og GCI's betydning i Danmark," i 200 år av kroppsbildning: Gymnastiska centralinstitutet/Gymnastik- och idrottshögskolan 1813-2013, red. Hans Bolling och Leif Yttergren (Stockholm: GIH, 2013), 133-60, Pia Lundquist Wanneberg, "Elin Falk, GCI och föreställningar om barnet - En analys av gymnastikstriden vid Stockholms folkskolor 1910-1913”, i 200 år av kroppsbildning. Gymnastiska centralinstitutet/Gymnastik- och idrottshögskolan 1813-2013, red. Hans Bolling och Leif Yttergren (Stockholm: GIH, 2013), 109ff; Suzanne Lundvall och Jane Meckbach, "Pionjärer med moraliskt mod - Ett sekel med en kvinnlig lärarutbildning i kroppsövning", i 2200 år av kroppsbildning. Gymnastiska centralinstitutet/Gymnastik- och idrottshögskolan 1813-2013, red. Hans Bolling och Leif Yttergren (Stockholm: GIH, 2013), 161-86. 


\section{Källmaterial}

Studien bygger på ett unikt, nyligen upptäckt och aldrig av forskningen tidigare använt källmaterial. Efter examen 1932 beslöt kvinnorna att fortsätta hålla kontakt med varandra via en så kallade vandringsbok. Den nionde september 1933 kan dateras som bokens födelsedatum, alltså drygt ett år efter examen. Initiativet till vandringsböckerna togs av norrländskan Berit Granqvist med smeknamnet "Mamma". Smeknamnen Mamma respektive Pappa gavs enligt traditionen på GCI till klassens ordningspersoner. Även de övriga i klassen erhöll med två undantag smeknamn: Ragnvi Montell och Zehra Thasin. Granqvist med flera utarbetade riktlinjer kring brevens omfång och hur boken skulle distribueras i klassen. Boken gick runt i klassen i elva varv. Ett varv kunde ta flera år. Det finns därmed ett stort antal berättelser från varje kvinna i klassen med några undantag. Till exempel tog det första varvet tre år innan boken var tillbaka hos Granqvist och varv sex tog hela 12 år, men då ingrep Granqvist. Hon hämtade boken hos en kurskamrat där den enligt henne blivit liggande allt för länge och vidarebefordrade den själv till klasskamraterna i Stockholmsområdet. Hon ringde också kontinuerligt upp kamraterna ute i landet och drev på så att boken inte blev liggande. Flera av kurskamraterna vittnar om detta i sina brev.

Vandringsböckerna består av 12 volymer inbundna anteckningsböcker á cirka 200 sidor, och täcker perioden 1933-1992. Kvinnorna själva benämnde böckerna "Vår Bok". År 2002 överlämnades de till Gymnastik- och idrottshögskolan (GIH). Jag påträffade dem av en slump i GIH:s biblioteks arkiv. De ger inte bara insikt i de kvinnliga gymnastiklärarnas livsöden och karriärer utan öppnar upp till komparation med de kvinnliga kollegorna som utexaminerades 1893 från GCI, vilka också skrev i en vandringsbok i flera band och som sträckte sig över många decennier. Den förvaras också i GIH:s biblioteks arkiv. Dess innehåll har studerats och berörts i flera studier av Leif Yttergren och Hans Bolling samt även av Olle Halldén i en populärvetenskaplig skrift. ${ }^{16}$

Andra världskrigets utbrott 1939 påverkade distributionen av boken. Granqvist var rädd att den skulle försvinna på grund av den osäkra postgången och därför bestämdes att den så länge kriget pågick inte fick skickas utanför Sveriges gränser. Detta drabbade tre av kvinnorna i klassen vilka alla var verksamma utomlands: Vivian "Babs" Holm hade flyttat till Island efter examen, turkiskan Zehra Thasin hade återvänt hem till Turkiet och Carin "Kicki" Högberg bodde i Kairo i Egypten.

Redan från bokens början utvecklades spontant en informell mall om hur breven skulle utformas. Mallen förändrades över tid för vart varv boken gick runt i klassen i takt med att kvinnornas liv och karriärer ändrades. Inledningsvis behandlade breven mest yrkeskarriären, var man fått arbete, arbetsplatsens för- och nackdelar, vilka arbetsuppgifter som ingick, ibland omnämndes lönen, men även personliga reflektioner kring resor, relationer med mera kommenterades. I takt med förändrade familjeförhållanden ändrades dock innehållet i breven och blev mer personligt hållna. Från och med femte och sjätte varvet har breven ett innehåll som bäst kan beskrivas som "familjenytt". Anmärkningsvärt få politiska och samhällsorienterade

16 Yttergren och Bolling (2016); Hans Bolling och Leif Yttergren, "Swedish Gymnastics for Export: A Study of the Professional Careers and Lives of Swedish Female Gymnastic Directors, 1893-1933," International Journal of the History of Sport 32, no. 11-12 (2015), 1437-55; Olle Halldén, Vandringsboken: En 50-årig korrespondens mellan kvinnliga gymnastikdirektörer (Stockholm: HLS-Förlag, 1996). 
ämnen togs upp i breven. Inte ens jämställdhetsfrågan omnämndes. Arbetet och familjen, "den lilla historien" stod i fokus och kring dessa teman är vandringsboken en rik källa att gräva ur.

En källkritisk reflektion är också på sin plats. Breven ger kvinnornas egen bild av sin livshistoria och yrkeskarriär. Det är således en subjektiv berättelse och sällan tas livets mörka sidor upp. Möjligen var inte vandringsboken rätt forum för detta utan personliga svårigheter avhandlades kanske i brev, telefonsamtal eller samtal kvinnorna mellan. Samtidigt ska påpekas att i de sista volymerna är breven något mer öppenhjärtiga angående personliga problem.

Vandringsböckernas rika innehåll har vid behov kompletterats med tryckt och otryckt material i GCI:s arkiv i Riksarkivet. Det materialet kompletteras med data ur den numera av Riksarkivet digitaliserade folk- och kyrkobokföringen i syfte att besvara de biografiska frågeställningarna.

\section{Metod}

En kollektivbiografisk metod har använts där GCI-kvinnornas bakgrund, karriärer och livsöden samlats in efter vissa givna kriterier och sedan analyserats. Metoden används ofta vid undersökningar av människor som tillhör en yrkeskategori och för vilka samma typ av data (ålder, kön, födelseort, föräldrar, bostadsort med mera) går att samla in. Den ger möjlighet att sammanställa enskilda kvinnors livsmönster och yrkeskarriärer. Genom att ta del av kvinnornas levnadsberättelser framträder både för- och nackdelar med yrkena, och kompletteras detta med andra källor kan kvinnornas levnadsberättelser placeras in i ett historiskt och kulturellt sammanhang. ${ }^{17}$

Kvinnorna höll inte bara kontakten via brevskrivandet utan sågs även vid återkommande jubileumsträffar. De ägde rum med fem års mellanrum mellan 1937 och 1997. Vidare var intresset stort för fortbildningskurser och föreläsningar på GCI, ofta anordnade av Föreningen GCI, och där träffades också kvinnorna om möjlighet fanns. Det uppstod en stark samhörighet i klassen och en stark identitet med yrkesvalet bland kvinnorna. Kvinnorna som bodde i Stockholm respektive Göteborgsområdet träffades med viss regelbundenhet och några blev också nära vänner med flitig kontakt.

I denna artikel fokuseras perioden 1932-1973 då denna tid torde ha varit den mest aktiva för kvinnorna vad gäller yrkeskarriär och familjebildning. De flesta gick nämligen i pension kring 1970. År 1997 hade den sammansvetsade klassen sin sista återförening, 65 år efter examen, på Varbergs kurortshotell med nio deltagare. Den tolfte och sista vandringsboken slutade våren 1992. Intresset fanns då kvar att läsa i boken men däremot hade intresset att skriva i boken hade svalnat. Det skrevs då om förväntningarna inför det kommande 60-årsjubileet av examen 1932 senare under sommaren. I denna sista bok finns också en förteckning över de som avlidit. År 1992 fanns 20 kvinnor av 32 kvar i livet och de var omkring 80 år gamla.

\section{Utbildningen vid GCI}

GCI gick tidigt i bräschen för högre professionsutbildning för kvinnor i Sverige; utbildningen öppnades för dem redan 1864. Från 1887 uppgraderades examenstiteln

17 Se även Donald Broady, Formering för offentlighet: En kollektivbiografi över Stockholmskvinnor 1880-1920 (Uppsala: Uppsala universitet, 1998). 
på GCI både för män och kvinnor till gymnastikdirektör, en titel som fortlevde på institutet, då under namnet Gymnastik- och idrottshögskolan, till 1977. Totalt utexaminerades 673 kvinnor från GCI under perioden $1865-1912 .{ }^{18}$ De manliga studenternas utbildning var treårig och innehöll tre separata kurser (utbildningsprogram): militära instruktörskursen, idrottslärarkursen och sjukgymnastkursen. De manliga studenternas utbildningsstrategi skilde sig från kvinnornas. Många män, de flesta militärer, valde att bara genomgå två kurser (två år) på GCI och var därmed inte behöriga att ta ut gymnastikdirektörsexamen. ${ }^{19}$

Under perioden 1913-1932 genomgick 595 kvinnor GCI:s utbildning fördelat på 20 klasser. Antalet antagna per år var mellan 26 och 34 kvinnor. Det var således bara en klass per år som antogs. Ur ett sentida perspektiv var genomströmningen anmärkningsvärt stor. Alla 595 tog examen och erhöll därmed gymnastikdirektörstiteln..$^{20}$

En tidigare studie visar att kvinnorna före 1900 efter examen i "brist på tillräckligt avlönade gymnastiklärarinneplatser" var hänvisade till eller valde att ägna sig åt sjukgymnastik i privat regi, antingen på ett större privatägt institut, eget institut eller på egen mottagning. Antalet tjänster som idrottslärare var få och utbildningen på GCI var i praktiken en sjukgymnastutbildning, åtminstone för kvinnor. ${ }^{21}$ Kring 1900 förbättrades möjligheterna till lönearbete inom skolväsendet då gymnastikämnet blev mer och mer obligatorisk samtidigt som sjukgymnaster började anställas vid de större sjukhusen och efterhand blev sjukgymnasterna en allt mer frekvent yrkeskategori vid landets sjukhus, vilket också märktes i var de studerade kvinnorna arbetade.

I början av 1930-talet var GCI en relativt liten utbildningsanstalt. Den leddes av en direktion, motsvarande högskolestyrelse idag, bestående av fem personer: fyra män och en kvinna. ${ }^{22}$ Elin Falk var enda kvinnan i direktionen och en känd profil i gymnastikkretsar. Hon hade också gått GCI i slutet av 1890-talet. ${ }^{23}$ Den undervisande personalen var uppdelad i olika lärarkategorier: tre överlärare, två lärare, två lärarinnor, åtta extralärare, fem extralärarinnor och åtta biträdande lärare och lärarinnor. ${ }^{24}$

Militärer var den överlägset största enskilda yrkeskategorin av den manliga undervisande personalen. De kvinnliga lärarna var föga förvånande utbildade gymnastikdirektörer. ${ }^{25}$ Officeren och gymnastikledaren Gerhard Winroth var föreståndare (rektor) för GCI och hade tillträtt posten 1930 och blev kvar i sju år.

18 Kungl. Gymnastiska centralinstitutets historia 1813-1913 (Stockholm, 1913), 380-96.

19 Betygsjournaler 1913-1932 (DVIIb2+3), GCI:s arkiv, Riksarkivet.

20 Betygsjournaler 1913-1932 (DVIIb2+3), GCI:s arkiv, Riksarkivet. En kvinnlig student tog inte examen på grund av sjukdom men återkom året efter sjukfrånvaron till GCI och tog då sin examen.

21 Yttergren och Bolling (2016), 204-8.

22 Till detta ska läggas två revisorer och en sekreterare.

23 Lundquist Wanneberg (2013), 109-10.

24 Kungl. Gymnastiska Centralinstitutet, Redogörelse för institutets verksamhet under arbetsåret 19301931 (Stockholm, 1931). Det är oklart vad de biträdande lärarna och extralärarna hade för anställningsförhållanden samt relationen mellan dessa och de med tillsvidare anställning. Klart är att olika typer av vikariat var vanligt för gymnastikdirektörerna kring 1930 vilket också gällde 30 år tidigare.

25 Kungl. Gymnastiska Centralinstitutet, Redogörelse för institutets verksamhet under arbetsåret 19311932 (Stockholm, 1932). 
Vilka ämnen undervisades kvinnorna i? Här ska påpekas att den praktiska undervisningen var uppdelad efter kön, men att samundervisning skedde till viss del i teoretiska ämnen. ${ }^{26}$ Det dröjde till läsåret 1977/78 innan praktisk samundervisning infördes vid GIH. ${ }^{27}$

Undervisningen var uppdelad i två huvuddelar: teoretiska och praktiska ämnen. De förstnämnda bestod av anatomi, fysiologi, pedagogisk gymnastik, sjukdomslära, fysikaliska terapins teori, lek och idrott. De praktiska ämnena bestod av pedagogisk gymnastik (personlig färdighetsträning), sjukgymnastik, lek och idrott. Stor vikt lades uppenbart vid att utveckla den egna personliga färdigheten hos studenterna. ${ }^{28}$ Betyg gavs i ovan nämnda ämnen i fyra steg: med utmärkt beröm godkänt, med beröm godkänt, med utan beröm godkänt, icke utan beröm godkänt. ${ }^{29}$

Sammanfattningsvis genomgick kvinnorna sin utbildning vid GCI när lärosätet fortsatt stod för en prestigeutbildning starkt förankrad i den lingska traditionen. Men det skulle inte dröja länge förrän både GCI och linggymnastiken började ifrågasättas. Att utbildningen av sjukgymnaster flyttades från GCI till Karolinska institutet 1934 innebar en avgörande förändring, både för GCI och dess studenter. ${ }^{30} \mathrm{GCI}$ kunde därmed inte längre erbjuda två professionsutbildningar inom ramen för en gymnastikdirektörsexamen, vilket drabbade de kvinnliga studenterna på GCI.

\section{Resultat \\ Kvinnornas sociala tillhörighet}

På 1930-talet var det få personer i Sverige som fortsatte till universitet- och högskolestudier; högre utbildning var fortsatt ett privilegium för samhällets övre skikt, i synnerhet för den manliga delen. Här kan nämnas att 1930 tog 2248 elever studentexamen och 40 år senare var antalet $29702 .{ }^{31}$ Samtidigt var utbildningssystemet inne i en jämställdhetsprocess under mellankrigstiden där flickor i högre utsträckning gavs möjlighet, åtminstone teoretiskt till studier. År 1927 fick flickor nämligen tillträde till de allmänna läroverken i samband med en större skolreform och därmed ökad chans att fortsätta till högre studier. ${ }^{32}$

En undersökning av den sociala sammansättningen av de kvinnliga studenterna som gick ut GCI 1893 ger vid handen att de kom nästan uteslutande från samhällets övre skikt. Hur var det då 1932? Hade den sociala sammansättningen ändrats i takt med samhällets demokratisering och ökade möjligheter för arbetar- och medelklassen att utbilda sig efter folkskolan? Resultaten tyder på att så var fallet.

26 Jubileumsskrift: Föreningen G.C.I. 1902-2002 (Stockholm, 2003), 138-39.

27 Kungl. Gymnastiska Centralinstitutet, Gymnastik- och idrottshögskolan i Stockholm 1963-1988 (Stockholm, 1988), 166.

28 Kungl. Gymnastiska Centralinstitutet (1932), 17-19.

29 Protokoll hållet vid avslutning med kvinnliga kurselever den 28 maj 1932, Kollegiets protokoll (AII, vol. 6), GCI:s arkiv, Riksarkivet.

30 Bolling och Yttergren (2013), 44-45.

31 Gunnar Richardson, Svensk utbildningshistoria: Skola och samhälle förr och nu (Lund: Studentlitteratur, 1999), 61.

32 Richardson (1999), 78-79. 
Tabell 1. Fädernas yrke i den kvinnliga avgångsklassen vid GCI 1932.

\begin{tabular}{|l|l|}
\hline Yrke & Antal \\
\hline Företagare/handlande/fabrikörer & 6 \\
\hline Militärer & 1 \\
\hline Akademiker & 11 \\
\hline Kontorsanställda & 8 \\
\hline Hantverkare & 2 \\
\hline Arbetare & 1 \\
\hline Jordbrukare & 2 \\
\hline Ospecificerade & 0 \\
\hline Felande uppgifter & 1 \\
\hline Summa & 32 \\
\hline
\end{tabular}

Källa och kommentar: Födelseböcker (digitaliserade, Riksarkivet) från församlingarna kvinnorna var födda i. Den felande uppgiften är turkiskan Zehras Thasin far. Hans yrke har inte gått att fastställa.

Kvinnorna kom ur samhällets olika skikt med en klar övervikt från mellanskiktet och övre mellanskiktet. Akademikerkategorin var störst och där återfanns yrken som ingenjör, tandläkare, läkare, musikdirektör, komminister med flera. Gruppen kontorsanställda, inkluderande bland annat yrken som kammarskrivare och tjänstemän, var den näst största gruppen följd av företagarna (handlande, handelsdirektör med flera). Hantverkar- och arbetargruppen utgjordes av tre personer: Sissi "Cecilia" Borgerts far var snickare och Astrid "Knoppen" Svenssons far var kakelugnsmakare. Skånskan Wera "Jeppa" Perssons far arbetade som lokförare. ${ }^{33}$ I en jämförelse med kvinnorna som utexaminerades 1893 hade det skett en social breddning, en medelklassifiering. Bland annat kan noteras att kvinnor från adelsfamiljer saknades helt medan akademikerna och kontorsanställda blivit flera. Arbetar- och hantverkargrupperna var fortsatt klart underrepresenterade. Uppenbart var högskolestudier ännu inget alternativ för unga kvinnor ur arbetarklassen. ${ }^{34}$

\section{Kvinnornas geografiska hemort}

Det kan noteras att rekryteringen till GCI var nationell och skedde från landets olika delar. Elva av 32 kom från huvudstaden. Vad gäller de övriga kom två från Norrland, åtta från övriga Svealand, tio från Götaland och en från utlandet. Frances "Fockie" Foucard var trots det utlandsklingande namnet född i Stockholm. Hon förblev ogift livet igenom och arbetade större delen av sin karriär i Åmål i Dalsland på en gymnasieskola som idrottslärare. Foucard hade engelska föräldrar, fadern var ingenjör. ${ }^{35}$

Stora delar av landet var således representerat i klassen. Dessa kvinnor lämnade därmed hemmet och hembygden i unga år och flyttade till huvudstaden för att satsa på högre utbildning. I Stockholm bodde de nästan alla i innerstaden, förmodligen inneboende, med närhet till GCI vid Hamngatan. ${ }^{36}$ Den mest långväga studenten var

33 Borgert, Jeppsson, födelsebok, födelseförsamling, Riksarkivet.

34 Bolling och Yttergren (2015), 1437-55.

35 Vandringsböcker, Frances Foucard, Födelseböcker, Frances Foucard, Församlingsbok, Riksarkivet.

36 Kungl. Gymnastiska Centralinstitutet, Direktion, lärare och elever 1931-1932 (Stockholm 1931), 10-11. Två av kvinnorna bodde på Lidingö och en i Stocksund. 
turkiskan Zehra Tahsin, som 26 år gammal inte bara flyttade till Sverige från Turkiet utan också lärde sig svenska för att kunna genomföra utbildningen. Zehra klarade utbildningen och erhöll 1932 gymnastikdirektörstiteln. Hon var den enda utländska studenten. Zehra skrev sporadiskt i vandringsböckerna efter hemkomsten till Turkiet. Hon blev senare en känd gymnastik- och idrottsprofil i Turkiet och var bland annat ledare för de kvinnliga turkiska fäktarna i Berlin-OS 1936. I Berlin träffade hon flera av sina kurskamrater som var med i den svenska massuppvisningstruppen i gymnastik. Hon fick även besök i Turkiet av några kvinnor från klassen, vilket också understryker den starka samhörigheten i gruppen. ${ }^{37}$

En annan som omgående lämnade Sverige efter examen var Vivian "Babs" Holm, född i Rasbo socken i Uppland. Hon flyttade till Island där hon gifte sig med en sjukgymnast, förmodligen GCI-utbildad. På Island arbetade hon som sjukgymnast, trots flitigt barnafödande och skilsmässa. Hon fick fyra barn på relativt kort tid. Efter skilsmässan gifte hon om sig med en präst i slutet av 1940-talet. "Babs" stannande på Island resten av sitt liv och var anställd vid samma privatpraktik under 30 år, 1948-1978. Hon slutade vid 68 års ålder i samband med att praktiken stängdes. "Babs" Holm engagerade sig även fackligt och var ordförande i landets sjukgymnastförening 1955-1967..$^{38}$

När det gäller 1893 års studenter kan noteras att de flesta var födda i Svealand, sju i Götaland, fyra i Norrland och fem utomlands - två i Finland och en vardera i Danmark, England och Norge. De som tog examen härrörde alltså från hela Sverige och det internationella inslaget i klassen var betydande. ${ }^{39}$

År 1932 hade detta således delvis förändrats. Stockholmsdominansen fanns kvar, vilket inte är märkligt med tanke på att Stockholms befolkning ökat kraftigt mellan 1890 och 1930, från cirka 202000 till drygt 500000 invånare. Dessutom hade staden brett ut sig utanför tullarna och flera förorter hade etablerats. ${ }^{40}$ Stockholm var åtminstone teoretiskt på väg att bli en storstad med eget stort upptagningsområde till högskole- och universitetssfären. Den stora förändringen ligger i att antalet utlandsstudenter minskat från fem till en.

\section{Kvinnornas ålder vid utbildningsstarten}

Äldst var turkiskan Zehra Tahsin, född 1904 och de yngsta var födda 1910, med andra ord var åldersspannet mellan 20 och 26 år vid GCI-inträdet 1930. Totalt 27 kvinnor av 32 var födda åren 1909 och 1910 och de var således endast kring 20 år när de började på GCI och 22 år vid examen. De var därmed relativt unga och hade nästan omgående gått från motsvarande gymnasiestudier till GCI i Stockholm. Åldersmässigt var de således även en relativt homogen grupp vid inträdet i den gymnastiska högborgen vid Hamngatan i Stockholm. ${ }^{41}$ Vid en jämförelse med den kvinnliga studentgruppen som tog examen 1893 finns en viss skillnad. Den hade en medelålder

\footnotetext{
37 Vandringsböcker, Zehra Tahsin.

38 Vandringsböcker, Vivian "Babs" Holm.

39 Yttergren och Bolling (2016), 204-8.

40 http://statistik.stockholm.se/images/stories/pdf/Historisk_befolkning_web.pdf.

41 Tyvärr är kvinnornas ansökningshandlingar utgallrade på Riksarkivet, vilket gör det svårt att veta något om deras skolgång före GCI-tiden. Klart är att många hade goda språkkunskaper, något som var en förutsättning för arbete på utländska gymnastikinstitut.
} 
på drygt 24 år, den yngsta hade just fyllt 21 och den äldsta fyllde 29 år när de började på GCI. ${ }^{42}$

Kvinnorna blev förhållandevis gamla och avled med ett undantag mellan 1977 och 2013. De två äldsta, Inga "Jackie" Janson var 103 år när hon avled. Ett år äldre blev Wera "Jeppa" Persson från Helsingborg. Hon arbetade först som sjukgymnast med olika vikariat, bland annat i Helsingborg, Varberg, Umeå och var även i Paris i två år på 1930-talet. Hon var sedan hemmafru under många år, men startade sedan ett eget institut i Sigtuna på 1960-talet.

Ett undantag vad gäller ålder var dalkullan Hjördis "Orsa" Grindal. Hon avled redan 1951 i cancer efterlämnande man och tre småbarn. Hon stack ut även på ett annat sätt då hon tämligen omgående lämnade yrket för fabriksarbete och sedan vidareutbildade hon sig till personaladministratör vid Socialhögskolan. Hon var således den enda av kvinnorna som dog i förtid, det vill säga före pension. ${ }^{43}$ GCI-kvinnorna blev i genomsnitt drygt 83 år. ${ }^{44}$

\section{Kvinnornas yrkeskarriär}

Formellt sett hade de som nämnts ovan behörighet att arbeta som både sjukgymnast och idrottslärare. En rad olika sysselsättningar har noterats som kvinnorna ägnade sig åt inom ramen för sin examen. De är indelade i huvudsysselsättning (A) och bisyssla (B):

A: idrottslärare, sjukgymnast på institut, kurort, sjukhus av skilda slag, egen företagare inom sjukgymnastik, sjukgymnast hos privatperson, annan yrkeskarriär B: simlärare, gymnastikinstruktör i föreningar

Alla fick således anställning efter examen inom det verksamhetsområde de utbildat sig i. Här skall påpekas att anställningarnas karaktär varierade kraftigt både vad gäller innehåll och varaktighet. Under de första åren efter examen agerade de flesta kvinnor efter en likartad handlingsstrategi. Kvinnorna tackade ja till alla möjliga lönearbeten, många gånger korta vikariat, för att få praktik och inte minst en stadig inkomst. De hoppade mellan olika anställningar och geografiskt avstånd var inget hinder utan de var synnerligen mobila och tog anställningar i olika delar av Sverige. Efterhand fick många fast anställning och blev då kvar i många år på samma arbetsplats, ofta som idrottslärare på någon skola. Några sökte sig till och med utomlands. Göteborgskan Inga "Jackie" Janson kan tjäna som ett typexempel. Hösten 1932 arbetade hon som:

- biträdande gymnastiklärare vid Högre allmänna läroverket för flickor 4 timmar i veckan

- $\quad$ sjukgymnast vid Göteborgs massagepoliklinik mellan kl. 8.30-14.30 med 20-25 patienter per dag, 10-15 minuter/patient och cirka 40 öre per patient (125 kr/mån)

- gymnastikinstruktör vid fem gymnastikklubbar 7 timmar i veckan. ${ }^{45}$

\footnotetext{
42 Yttergren och Bolling (2016), 198.

43 Vandringsböcker, Hjördis "Orsa” Grindal.

44 Statistiska Centralbyrån, http://www.statistikdatabasen.scb.se/pxweb/sv/ssd/START_BE_BE0101_ BE0101I/Medellivslangd/table/tableViewLayout1

45 Vandringsböcker, Inga ”Jackie” Jansson.
} 
Efterhand fick hon ett längre vikariat med flera timmar som idrottslärare vid "flickläroverket" i Göteborg och så småningom fast anställning. Hon blev kvar vid Kjellbergska läroverket i hela 35 år och över åren varierade antalet tjänstetimmar. Noteras bör också att hon födde fem barn under tiden 1935-1947, men fortsatte att arbeta direkt efter graviditeterna. Familjen tog dessutom i likhet med många andra i Sverige hand om en finsk flicka under kriget. ${ }^{46}$ Nämnas bör att de hade hembiträde, vilket troligen var en förutsättning för hennes fortsatta lärartjänstgöring. År 1953 framhåller hon att familjen inte längre har något hembiträde utan bara "en fru som lagar mat en gång i veckan". Skälet till detta var att Jackie hade ett bra schema med helledigt på fredagar trots 30 timmars tjänstgöring i veckan. Jackie gick i pension $1974 .{ }^{47}$

Endast två av kvinnorna lämnade tidigt yrket och valde en annan yrkeskarriär. Birgit "Billy" Andrén utbildade sig till folkskollärare efter GCI och arbetade bland annat i Abrahamnsbergskolan och Olofslundsskolan i Stockholmsförorten Bromma där hon också bodde. Den andra var ovan nämnda "Orsa" Grindahl. Hon började arbeta i en kexfabrik och utbildade sig till personaladministratör. Under tiden arbetade hon som idrottslärare. ${ }^{48}$

Mobiliteten var således stor hos vissa av kvinnorna och uppenbart var behovet stort att ha en inkomstbringande tjänst med tanke på flyttningsbenägenheten. Wera "Jeppa" Persson var till och med på väg att tillträda en tjänst i USA på ett sjukgymnastikinstitut när hon träffade sin blivande man. Kärleken vann och hon hoppade av USA-resan och stannande kvar i Sverige. Hon gifte sig 1937 och fick barn sommaren 1938 och blev därefter hemmafru i 25 år. Hon återvände sedan till sjukgymnastiken och öppnade egen sjukgymnastpraktik. Hon hade patienter även efter uppnådd pensionsålder. ${ }^{49}$

I slutet av 1800-talet, "nervositetens tidsålder" var det inte ovanligt att sjukgymnaster arbetade hemma hos en välbeställd familj. Denna inkomstmöjlighet verkar vara på väg att försvinna för gymnastikdirektörerna under 1930-talet Agnes "Thulo" Thorburn utgör ett undantag. Hon arbetade en period hösten 1933 som assistent hos friherrinnan Sparre, vilken bodde i Nederländerna. ${ }^{50}$

Hur var det då med utlandsarbete bland kvinnorna? När det gäller den kvinnliga kursen som gick ut 1893 kan noteras att många arbetade i kortare eller längre perioder utomlands. Flera gånger vikarierade de för varandra i ett väl fungerande nätverk som uppenbart sträckte sig utanför landets gränser. USA, Finland, Tyskland, Schweiz, Frankrike, Danmark, England, Polen och Italien var länder som de utexaminerade gymnastikdirektörerna arbetade i. ${ }^{51}$ Att dessa kvinnor sökte sig utomlands var på intet sätt unikt. Theodor Bergquist, chef för Svenska Gymnastikanstalten i kurorten Bad Wörishofen i Tyskland, gav 1905 ut Svenska gymnastiken $i$ utlandet och dess representanter. 228 personer är med i bokens biografiska del, en majoritet av

46 Detta var inte ovanligt. Omkring 70000 finska barn skickades till Sverige under andra världskriget. Se Astri Andresen et al., Barnen och välfärdspolitiken: Nordiska barndomar 1900-2000 (Stockholm: Dialogos, 2011), 365-70.

47 Vandringsböcker, Inga "Jackie" Jansson.

48 Vandringsböcker, Birgit "Billy" Andrén.

49 Vandringsböcker, Wera "Jeppa" Persson.

50 Vandringsböcker, Agnes "Thulo "Thorburn.

51 Yttergren och Bolling (2016), 207. 
dem, 146 stycken, är kvinnor. ${ }^{52}$ Det fanns således en stor internationell arbetsmarknad för och ett internationellt nätverk av svenska gymnastikdirektörer med sjukgymnastisk inriktning, åtminstone kring sekelskiftet 1900.

På 1930-talet hade detta delvis ändrats. Fortsatt fanns det ett intresse för utlandsarbete och en efterfrågan på svenska sjukgymnaster. Det var bara de som efterfrågades, inte idrottslärarna. Hela tolv av de 32 kvinnorna flyttade utomlands av olika skäl till länder som Italien, Frankrike, Holland, Belgien, England, Egypten, Spanien och Island. Av dessa var det åtta som flyttade enbart för att arbeta som sjukgymnaster, de övriga fyra av andra skäl. Särskilt sjukgymnastarbete i Frankrike lockade kvinnorna, vilket överensstämmer med resultaten för 1890-talet. Det fanns sedan länge institut i Frankrike där svenska sjukgymnaster var etablerade. Däremot var det ingen som åkte över till USA för att arbeta, vilket förekom i slutet på 1890-talet och detta trots betydligt snabbare och bättre kommunikationer över Atlanten på 1930-talet.

Det verkar som goda kontakter var nyckeln till lönearbete. Ofta rekommenderade kvinnorna varandra till tjänster både i utlandet och i Sverige. Inte sällan ersatte de varandra på olika arbetsplatser. Det fanns också ett etablerat nätverk bland gymnastikdirektörer i Sverige där Föreningen GCI var spindeln i nätet.

Vidare har noterats att kvinnorna arbetade utomlands endast korta perioder och bara på 1930-talet. Två, tre år var vanligast och sen återvände man för gott till Sverige och i många fall väntade giftermål och barn och lönearbete på hemmaplan. Förmodligen var det så att förspelet och efterspelet till andra världskriget och givetvis kriget i sig påverkade arbetskraftsmobiliteten i Europa. ${ }^{53}$

Ett annat skäl till att intresset för utlandsarbete minskat framför Agnes "Thulo" Thorburn. Hon arbetade periodvis utomlands under 1930-talet, men ville inte vara utomlands för länge för att inte tappa i konkurrenskraft i Sverige. Uppenbart var det så att utlandsarbete inte var lika meriterande som lönearbete på hemmaplan för en sjukgymnast på 1930-talet. ${ }^{54}$

Resultaten stämmer delvis överens med en enkätundersökning som Föreningen GCI gjorde bland sina medlemmar om "Kvinnliga gymnastikdirektörers försörjningsförhållanden åren 1927-1931". Den visade att 1931 arbetade knappt 20 procent enbart som sjukgymnaster, 11 procent som idrottslärare (friskgymnaster), cirka 40 procent kombinerade dessa yrken. Hela 13 procent angav att "Försörjning omöjlig på grund av arbetsbrist", 16 procent hade lämnat yrket efter giftermål och 2 procent hade "Övergått till annat yrke". Utbildningen vid GCI var således i praktiken ingen garanti för lönearbete och en säker inkomst. Kvinnorna tvingades många gånger att ta korta vikariat runt om i Sverige annars hotade arbetslöshet och inkomstbortfall.

\section{Giftermål och familj}

I en tidigare studie framgår att av de kvinnor som utexaminerades från GCI 1893 gifte sig 13 av 25 kvinnor efter examen, drygt 50 procent. De som gifte sig gjorde det med något undantag relativt sent $\mathrm{i}$ livet, och när de provat på att vara ute $\mathrm{i}$ yrkeslivet

52 Theodor Bergquist, Svenska gymnastiken i utlandet och dess representanter (Stockholm: Nordin \& Josephson, 1905), 37-126.

53 Turkiskan Zehra Thasin flyttade tillbaka hem och Vivian Holm flyttade till Island för att både arbeta och gifta sig. Sissi Borgert bodde ett tag i Italien på grund av makens arbete. Inga Holmqvist jobbade ett tag på 1950-talet som reseledare i Spanien.

54 Vandringsböcker, Agnes Thurborn. 
en tid. När så skett valde de antingen giftermål och avslutad yrkeskarriär eller singelliv och fortsatt yrkeskarriär. Endast någon enstaka av kvinnorna fortsatte med sin yrkeskarriär efter giftermål. ${ }^{55}$

De kvinnliga gymnastikdirektörerna som gick ut GCI 1932 gifte sig i betydligt högre utsträckning och dessutom tidigare i livet och relativt snart efter att ha genomgått utbildningen. Hela 28 kvinnor av 32 gifte sig efter examen, många relativt omgående efter ha inlett sin inledningsvis ganska brokiga yrkeskarriär som idrottslärare och/eller sjukgymnast. Under perioden 1933-1943 hade 26 av 32 gift sig och två till gifte sig mellan 1944-1953. Fyra kvinnor, Agnes "Thulo" Thorburn, Frances "Fockie" Foucard, Ragnvi Montell, Margit "Majken" Salmén, var ogifta under hela sitt liv. Vidare kan noteras att äktenskapen var långvariga, oftast livslånga. Endast några stycken skilde sig eller separerade. Däremot var det drygt en handfull som tidigt blev änkor och av dessa gifte ett par om sig.

Tabell 2. De kvinnliga gymnastikdirektörerna civilstånd vid Gymnastiska centralinstitutet (GCI) i Stockholm 1933-1953

\begin{tabular}{l|llll} 
År & Gifta & Ogifta & Avlidna & Totalt \\
\hline 1933 & 5 & 27 & & 32 \\
1943 & 26 & 6 & & 32 \\
1953 & 27 & 4 & 1 & 32
\end{tabular}

Källa: Vandringsböcker 1933-1992 (GIH:s bibliotek), vol. I-V.

Kvinnorna som gick ut 1932 under mellankrigstiden valde således i betydligt större utsträckning giftermål än sina medsystrar på 1890-talet. Kan det ha berott på att handlingsutrymmet för kvinnor blivit större vid giftermål och att detta med automatik inte innebar avbruten yrkeskarriär och att bli hemmafru resten av livet? Hur kan det annorlunda giftermålsmönstret mellan 1890-talet och 1930- och 1940-talen förklaras? Tidigare forskning visar att det endast undantagsvis gick att förena giftermål och barn med fortsatt yrkeskarriär för 1890 -talets gymnastikkvinnor. ${ }^{56}$ Gymnastikkvinnornas handlingsutrymme var således stort fram till giftermålet. Till skillnad från 1890-talets GCI-kvinnor framkommer ingen enhetlig bild utan tre olika handlingsstrategier kan urskiljas: arbetslinjen, hemmafrualternativet, återvändningsstrategin.

Arbetslinjen innebar att kvinnorna fortsatte att arbeta tämligen omgående efter barnafödandet. Detta trots att barnpassning var ett ständigt problem, vilket flera av kvinnorna vittnar om i sina brev. Den offentliga barnomsorgen var som historikern K.G. Hammarlund visar i princip obefintlig på 1930-talet och det skulle dröja till 1960-talet innan den började byggas ut på allvar i samband med att kvinnorna i allt högre grad lämnade hemmet och började förvärvsarbeta. År 1965 yrkesarbetade nästan var tredje kvinna mot endast var tionde 20 år tidigare. ${ }^{57}$ Gymnastikkvinnorna var således föregångare bland de yrkesarbetande kvinnorna.

Kvinnorna kombinerade ju i hög grad lönearbete och familj. Uppenbarligen

55 Yttergren och Bolling (2016), 200-4.

56 Ibid.

57 K.G. Hammarlund, Barnet och barnomsorgen: Bilden av barnet i ett socialpolitiskt projekt (Göteborg: Göteborgs universitet, 1998), 108-12, 139-40. 
var barn och barnpassning en kvinnofråga. Ingen av kvinnorna nämner något om att mannen var hemma och tog hand om barnen, vilket ytterligare komplicerade livspusslet för kvinnorna. Lösningarna var många, ofta tog de hjälp av barnflickor. Anna-Lisa "Lulle" Ahlberg hade barnflickor som enligt henne "kommer och går". Sissie "Knäcken" Borgert hade hemhjälp som fick bo gratis hos familjen mot att hon hjälpte till i hushållet. Inga "Bam" Holmqvists mamma passade barnet under några år, men sen flyttade hon och då fanns det ingen annan utväg för henne än att ta med sig dottern till arbetet. Även Ebba "Quippe" Quiding och Greta "Truls" Östling, vilka drev ett gymnastikinstitut tillsammans i Västerås, arbetade vissa perioder halvtid och gick om lott på institutet för att få livspusslet barn och lönearbete att fungera. Ibland hade de också barnflickor. Britta "Pullan" Widman fick fyra barn och arbetade som idrottslärare. Hon ville gå ner på deltid, men tvekade för hon inte ville lämna en fast tjänst. Familjen skaffade därför ett hembiträde på 1940-talet för att hon skulle kunna fortsätta arbeta heltid: "För jag tycker alltjämt att vårt yrke är det bästa på jorden." Anna-Lisa "Jeddan” Jerdin fick barn sent i livet, vid 44 års ålder. I februari 1952 föddes sonen Jan och höstterminen 1954 började hon arbeta igen i Solna läroverk som idrottslärare.

Den andra strategin benämns hemmafrualternativet och innebar att kvinnorna lämnade yrket efter giftermål och barn och blev hemmafruar på heltid. Denna strategi verkar inte vara helt accepterad bland kvinnorna och de ursäktade sitt val. Till exempel Gull "Gloria" Schöler framhöll: "är själv fortfarande en fullkomlig avfälling." Detta alternativ var föga attraktivt och endast ett fătal av kvinnorna lämnade yrket för gott vid giftermål. Nämnda Gloria arbetade några år som sjukgymnast i bland annat Kalmar och verkade trivas med det. Hon träffade där sin blivande man som var jurist. De gifte sig 1937 och efter det återvände hon aldrig till yrket. Cirka 20 år efter examen skrev hon om sin situation: "hemmafru som vanligt och glad och nöjd med det." Hon fick tre barn. Hennes man gjorde däremot karriär.

Även Carin "Kicki” Högberg lämnade yrket och blev hemmafru/representationshustru efter giftermålet 1937. Innan dess arbetade hon som sjukgymnast bland annat på kurorten Sätra Brunn i Västmanland. Hennes man var norrman, välbeställd affärsman och honorärkonsul med verksamhet i Kairo. De bodde och verkade där under 24 år, men tvingades lämna landet i samband med störtandet av Kung Farouk i början av 1950-talet. Antieuropeiska stämningarna blev enligt "Kicki" för starka och familjen flyttade till Oslo. ${ }^{58}$ I övrigt var det som nämnts väldigt få av kvinnorna som valde hemmafrualternativet fullt ut.

Det tredje alternativet, återvändningsstrategin, innebar att kvinnorna lämnade yrket en tid för oavlönat arbete som hemmafru och återvände sedan till yrkeslivet. Till exempel Brita "Biffen" Westin fick tre barn och var först hemma med dom. "Biffen" började arbeta igen 1953, 21 år efter examen, och när det yngsta barnet var 5 år. Hon gjorde då karriär inom vården och i början av 1960-talet tillträdde hon en tjänst som chef på Göteborgs sjukgymnastiska poliklinik. En tjänst hon innehade till sin pension 1974. Greta "Truls" Östling arbetade efter examen som sjukgymnast bland annat på "Vaneföreanstalten" i Härnösand. Hon gifte sig 1937 och fick fem barn. Hon var hemmafru en tid innan hon startade ett sjukgymnastiskt institut i Västerås med kurskamraten "Quippe". Hon arbetade i varierad omfattning på institutet och

58 Vandringsböcker, Carin "Kicki” Högberg. 
fortsatte att behandla patienter i ytterligare 10 år efter pensionering och slutade arbeta först vid 77 års ålder.

Ytterligare ett exempel på denna återvändningsstrategi är Wera ”Jeppa” Persson. Efter examen 1932 hoppade hon runt på olika sjukgymnastvikariat på skilda platser i Sverige och i Paris. Hon arbetade också på kryssningsfartyget Gripsholm innan hon gifte sig 1937. Hon lämnade då arbetslivet: "Har full sysselsättning att sköta hem och barn.” Efter 25 år som hemmafru lockade åter yrkeslivet och 1962 anmälde hon sig till en så kallad reaktiveringskurs för sjukgymnaster. Efter den startade hon så småningom en egen sjukgymnastisk praktik i Sigtuna. Hon fortsatte att driva den och ha patienter även efter att ha uppnått pensionsåldern. ${ }^{59}$

Här kan således konstateras att giftermål och barn med några undantag inte innebar att kvinnorna gav upp sin yrkeskarriär. Många återgick tämligen omgående till sin tjänstgöring i varierad omfattning. Några gick ner i tid, andra valde bort att arbeta extra med att leda gymnastikföreningar, vilket ofta skedde på kvällstid och helger.

\section{Sammanfattande diskussion}

Syftet med artikeln har varit att analysera yrkeskarriärerna för de kvinnliga gymnastikdirektörernas, som gick ut GCI 1932. Kvinnorna emanerade ur samhällets mellanskikt och övre mellanskikt. En jämförelse med kvinnorna som gick ut 1893 ger vid handen att den årsklassen i betydligt större utsträckning kom från samhällets övre skikt. Åldersmässigt var gruppen som gick ut 1932 relativt homogen. De var kring 20 år när de började den tvååriga utbildningen på GCI. För många innebar detta också ett uppbrott från hemorten och en flytt till Stockholm. GCI-utbildningen lockade i princip studenter från hela landet. Studenterna från 1893 kom i stor utsträckning från Stockholm. Det gjorde också studenterna som gick ut 1932, vilket är logiskt med tanke på att Stockholms befolkning ökat kraftigt mellan 1890 och 1930, från cirka 200000 till drygt 500000 invånare. ${ }^{60}$

Även när det gäller giftermål skilde sig årgångarna åt. 28 av 32 gifte sig och dessutom tämligen omgående efter avslutad utbildning och under pågående yrkeskarriär. Vidare kan noteras att äktenskapen var långvariga. Kvinnorna som gick ut 1893 var betydligt mindre giftermålsbenägna. Endast 13 av 25 kvinnor gifte sig efter examen och det skedde relativt sent i livet när de hade varit ute i arbetslivet ett tag. Då stod de inför ett vägskäl i livet: antingen giftermål och avslutad yrkeskarriär eller singelliv och fortsatt yrkeskarriär. Den ökade giftermålsfrekvensen var inte unik för de kvinnliga gymnastikdirektörerna. Hans Nilsson och Lars-Göran Tedebrand konstaterar att under 1930- och 1940-talen skedde "en utomordentligt stark uppgång i giftermålsfrekvensen". De menar att detta hängde samman med strukturella faktorer men även med "kulturella och mentalitetsmässiga faktorer som fokusering på privatlivet, husmodersidealet och den begynnande konsumismen". ${ }^{61}$

Resultaten visar också att 1930-talets kvinnliga gymnastikdirektörer hade betydligt större handlingsutrymme och valde att arbeta, gifta sig och bilda familj trots att det innebar dubbelarbete och svårigheter att få ihop det så kallade livspusslet. 1930-talet var en tid när gifta kvinnors rätt till lönearbete diskuterades i samhället: yrkeskvinna eller hemmakvinna var frågan som ställdes. Det restes till och med krav

59 Vandringsböcker, Wera "Jeppa" Persson.

60 http://statistik.stockholm.se/images/stories/pdf/Historisk_befolkning_web.pdf.

61 Nilsson och Tedebrand (2005), 76. 
på begränsningar av gifta kvinnors rätt till arbete. År 1939 kom också en lag som stärkte kvinnans rätt på arbetsmarknaden i samband med giftermål och graviditet, men den innebar bara marginella förbättringar utifrån en sentida kontext. Till exempel kunde kvinnor avskedas om de tagit längre ledigt än 12 veckor efter det hon fött barn. ${ }^{62}$

Kommunal barnomsorg var ännu inget alternativ och det var inget de undersökta kvinnorna nämnde som ett alternativ för barnpassning. Istället var det olika lösningar, ofta barnflickor och/eller hembiträden, som många gånger gjorde att de undersökta kvinnorna kunde förvärvsarbeta i samband med familjebildning. Uppfinningsrikedomen var stor och arbetet många gånger prioriterat!

Det har noterats att kvinnorna agerade utifrån tre olika handlingsalternativ utan vattentäta skott emellan i samband med familjebildning: arbetslinjen, hemmafrualternativet, återvändningsstrategin. Det har visat sig att familjebildning endast $\mathrm{i}$ några enstaka fall innebar att kvinnorna lämnade arbetslivet för gott och blev hemmafruar. Många började arbeta tämligen omgående efter graviditeten i enlighet med arbetsmarknadens hårda krav. Återvändarna var ytterligare en kategori. De stannade hemma med barnen under en period och återvände till yrket när barnen blivit större.

Hur ska man då förklara att så många kvinnor återvände till yrket efter giftermål, vilket skiljer sig radikalt från 1890-talets handlingsstrategi bland de kvinnliga gymnastikdirektörerna? Förklaringen finns i tidsandan och samhällsutvecklingen från 1930-talet och framåt och den debatt som följde i Alva och Gunnar Myrdals omdiskuterade debattbok Kris i befolkningsfrågan från 1934. K.G. Hammarlund menar att från 1930-talet följde decennier av diskussion kring kvinnors förvärvsarbete och barnomsorg. ${ }^{63}$ Parallellt började det spridas en uppfattning i samhället om att kvinnors förvärvsarbete bidrog till samhällets välstånd och inte var ett hot mot männens försörjningsmöjligheter. ${ }^{64}$

Gymnastikkvinnorna var något av spjutspetsar i denna omvandlingsprocess, vilket understryks av att bara 10 procent av de gifta kvinnorna förvärvsarbetade på 1930-talet. År 1945 hade denna siffra ökat till drygt 14 procent och till 24 procent 1960. GCI-kvinnorna var således mer lönearbetsbenägna än andra kvinnor på 1930-talet även efter giftermål. ${ }^{65}$ GCI-kvinnornas lönearbetsbenägenhet kan kanske förklaras utifrån yrkets fostrande och vårdande karaktär. Lärar- och sjukgymnastyrket kan ses som ett kall likt sjuksköterskans och läkarens. Även den starka klasssammanhållningen och GCI-andan kan ha spelat in i viljan att arbeta. Begreppet "avfälling" används av kvinnorna själva när de inte förvärvsarbetade utan var hemmafruar.

Utbildningen på GCI innebar att kvinnorna kunde arbeta som sjukgymnaster och idrottslärare samt arbeta extra som instruktörer inom gymnastikrörelsen. Teoretiskt föreföll således möjligheterna till lönearbete goda, men i verkligheten var hand-

62 Catharina Calleman, "Befolkningskriserna och arbetsrätten," i Familjeföreställningar: Om familjens betydelse inom juridik, ekonomi och forskning, red. Monica Burman och Åsa Gunnarsson (Uppsala: Iustus, 2001), 254-58; Katarina Larsson, Andrahandskontrakt i folkhemmet: Närmiljö och kvinnors förändringsstrategier (Örebro: Örebro Studies in History, 2005), 133-36.

63 Hammarlund (1998), 41.

64 Ibid., 173.

65 Ibid., 85. 
lingsutrymmet begränsat för kvinnorna. De nödgades till att ta det lönearbete som gavs oavsett var det fanns i landet. I början var det ofta korta vikariat som sjukgymnaster eller idrottslärare, ibland kombinerade man dessa. Denna strategi verkade emellertid fungera och efterhand erhöll många fasta tjänster. Några startade också sjukgymnastiska institut. Endast två av kvinnorna lämnade yrket för annan yrkesverksamhet. Även lönearbete utomlands lockade drygt ett tiotal av kvinnorna, vilket stämmer väl överens med kvinnorna som gick ut 1893 . En viktig skillnad kan dock noteras. De sistnämnda verkade utomlands i långa perioder medan 1932 års årgång tog korta vikariat efter examen innan de återvände hem till Sverige. Uppenbart var inte utlandstjänstgöring lika attraktivt längre på 1930-talet. En förklaring till detta antyds i breven. Utlandsarbete var inte lika meriterande som att arbeta i Sverige och i jakten på en fast anställning var meriteringen uppenbart viktig.

I likhet med kvinnorna som gick ut 1893 var sjukgymnastyrket något som lockade kvinnorna i minst lika hög utsträckning som idrottsläraryrket. Det starka sjukgymnastiska inslaget har i GCI/GIH:s egen historieskrivning hållits tillbaka.

Tidigare forskning har diskuterat huruvida mellankrigstidens kvinnor var yrkeskvinnor eller "makens tjänarinna" för att tala med Renée Franguer. Historikern Yvonne Hirdman menar att under folkhemseran var det rådande genuskontraktet det så kallade "husmoderskontraktet". Perioden mellan 1930 och 1960 kännetecknades av att detta kontrakt rådde i samhället, vilket innebar att kvinnan var hemma, den goda husmodern, och skötte barn och hem. Mannen däremot tog hand om lönearbetet och försörjde därmed familjen. ${ }^{66}$ Frangeur menar däremot att gifta kvinnor sökte sig till arbetsmarknaden i allt större utsträckning redan under 1930-talet och att fler kvinnor "bejakade det moderna förvärvsarbetet", ${ }^{67}$ vilket stämmer väl överens med gymnastikkvinnornas agerande. De förenade i de flesta fall en stark identitet som yrkeskvinna med hemmafrurollen och återvände till yrket så fort lagstiftningen krävde detta eller när barnen blivit äldre eller när barnpassningen lösts. Hemmafrurollen var inget permanent alternativ för gymnastikkvinnorna. Längtan till lönearbetet var starkare.

66 Yvonne Hirdman, Demokrati och makt i Sverige: Maktutredningens huvudrapport, SOU 1990:44, $84-87$.

67 Frangeur (1998), 67. 


\section{Referenser \\ Arkiv \\ Riksarkivet \\ GCI:s arkiv \\ Betygsjournaler. \\ Kollegiets protokoll. \\ GIH:s biblioteks arkiv \\ Vandringsböcker}

\section{Litteratur}

Andresen, Astri, Ólöf Garðarsdóttir, Monika Janfelt, Cecilia Lindgren, Pirjo Markkola och Ingrid Söderlind. Barnen och välfärdspolitiken: Nordiska barndomar 1900-2000. Stockholm: Dialogos Förlag, 2011.

Bergquist, Theodor. Svenska gymnastiken i utlandet och dess representanter. Stockholm: Nordin \& Josephson, 1905.

Bolling, Hans och Leif Yttergren. "Swedish Gymnastics for Export: A Study of the Professional Careers and Lives of Swedish Female Gymnastic Directors, 18931933." International Journal of the History of Sport 32, no 11-12 (2015).

Broady, Donald. Formering för offentlighet: En kollektivbiografi över Stockholmskvinnor 1880-1920. Uppsala: Uppsala universitet, 1998.

Calleman, Catharina, "Befolkningskriserna och arbetsrätten." I Familjeföreställningar: om familjens betydelse inom juridik, ekonomi och forskning, red. Monica Burman och Åsa Gunnarsson. Uppsala: Iustus, 2001.

Carli, Barbro. The Making and Breaking of a Female Culture: The History of Swedish Physical Education "in a different voice." Göteborg: Acta Universitatis Gothoburgensis 2004.

Fletcher, Sheila. "The Making and Breaking of a Female Tradition: Women's Physical Education in England 1880-1980." British Journal of Sports History 2, no. 1 (1985).

Florin, Christina. Kampen om katedern: Feminiserings- och professionaliseringsprocessen inom den svenska folkskolans lärarkår 1860-1906. Umeå: Umeå universitet, 1987.

Frangeur, Renée. Yrkeskvinna eller makens tjänarinna: Striden om yrkesrätten för gifta kvinnor i mellankrigstidens Sverige. Eslöv: Symposion, 1998.

Halldén, Olle. Vandringsboken: En 50-årig korrespondens mellan kvinnliga gymnastikdirektörer. Stockholm: HLS-Förlag, 1996.

Hammarlund, K.G. Barnet och barnomsorgen: Bilden av barnet $i$ ett socialpolitiskt projekt. Göteborg: Göteborgs universitet, 1998.

Hirdman, Yvonne. Demokrati och makt i Sverige: Maktutredningens huvudrapport. SOU 1990:44.

Hirdman, Yvonne, "Genusanalys av välfärdsstaten: En utmaning av dikotomierna." I Fra kvinnehistorie til kjönnshistorie, Rapport 3 från det 22. nordiske historikermøde, red. Kari Melby och Kåre Tønnesson. Oslo: IKS, 1994.

Jubileumsskrift: Föreningen G.C.I. 1902-2002. Stockholm, 2003.

Kungl. Gymnastiska centralinstitutets historia 1813-1913. Stockholm, 1913. 
Kungl. Gymnastiska Centralinstitutet. Redogörelse för arbetsåret 1930-1931. Stockholm, 1931.

Kungl. Gymnastiska Centralinstitutet. Direktion, lärare och elever 1931-1932. Stockholm, 1931.

Kungl. Gymnastiska Centralinstitutet. Redogörelse för arbetsåret 1931-1932. Stockholm, 1932.

Kungl. Gymnastiska Centralinstitutet. Gymnastik- och idrottshögskolan i Stockholm 1963-1988. Stockholm, 1988.

Larsson, Katarina. Andrahandskontrakt i folkhemmet: Närmiljö och kvinnors förändringsstrategier. Örebro: Örebro Studies in History, 2005.

Lindroth, Jan. Idrottens väg till folkrörelse: Studier i svensk idrottsrörelse till 1915. Uppsala: Acta Universitatis Upsaliensis, 1974.

Lindroth, Jan. Gymnastik med lek och idrott: För och mot fria kroppsövningar i det svenska läroverket 1878-1928. Stockholm: HLS-Förlag, 1993.

Lindroth, Jan. Ling - från storhet till upplösning: Studier i svensk gymnastikhistoria 1800-1950. Stockholm: SISU Idrottsböcker, 2004.

Ljunggren, Jens. Kroppens bildning: Linggymnastikens manlighetsprojekt 1790-1914. Eslöv: Symposion, 1999.

Lundquist Wanneberg, Pia. Kroppens medborgarfostran: Kropp, klass och genus i skolans fysiska fostran 1919-1962. Stockholm: Stockholms universitet, 2004.

Lundquist Wanneberg, Pia. "Elin Falk, GCI och föreställningar om barnet: En analys av gymnastikstriden vid Stockholms folkskolor 1910-1913." I 200 år av kroppsbildning. Gymnastiska centralinstitutet/Gymnastik- och idrottshögskolan 18132013, red. Hans Bolling och Leif Yttergren. Stockholm: GIH, 2013.

Lundvall, Suzanne och Jane Meckbach. Ett ämne i rörelse: Gymnastik för kvinnor och män i lärarutbildningen vid Gymnastiska centralinstitutet/Gymnastik- och idrottshögskolan under åren 1944 till 1992. Stockholm: HLS-Förlag, 2003.

Lundvall, Suzanne och Jane Meckbach. "Pionjärer med moraliskt mod - Ett sekel med en kvinnlig lärarutbildning i kroppsövning.” I 200 år av kroppsbildning. Gymnastiska centralinstitutet/Gymnastik- och idrottshögskolan 1813-2013, red. Hans Bolling och Leif Yttergren. Stockholm: GIH, 2013.

Lykke Poulsen, Anne. "Den kvindelige Kvinde:" Kampe om kvindelighed, medborgarskab og professionalisering i dansk kvindegymnastik 1886-1940. Köpenhamn: Köpenhamns universitet, 2005.

Nilsson, Hans och Lars-Göran Tedebrand. Familjer $i$ växande städer: Strukturer och strategier vid familjebildning i Sverige 1840-1940. Umeå: Umeå universitet, 2005.

Ottosson, Anders. Sjukgymnasten - vart tog han vägen: En undersökning av sjukgymnastyrkets maskulinisering och avmaskulinsering 1813-1934. Göteborg: Göteborgs universitet, 2007.

Richardson, Gunnar, Svensk utbildningshistoria: Skola och samhälle förr och nu. Lund: Studentlitteratur, 1999.

Sommestad, Lena. Från mejerska till mejerist: En studie av mejeriyrkets maskuliniseringsprocess. Lund: Arkiv, 1992.

Trangbaek, Else. "Sally Högström og det moderne kvindeprojekt - Svensk gymnastik og GCI's betydning i Danmark." I 200 år av kroppsbildning. Gymnastiska centralinstitutet/Gymnastik- och idrottshögskolan 1813-2013, red. Hans Bolling och Leif Yttergren. Stockholm: GIH, 2013. 
Wikander, Ulla. "Delat arbete, delad makt." I Kontrakt $i$ kris: Om kvinnors plats $i$ välfärdsstaten, red. Gertrud Åström och Yvonne Hirdman. Stockholm: Carlsson, 1992.

Yttergren, Leif. Täflan är lifvet: Idrottens organisering och sportifiering i Stockholm 1860-1898. Stockholm: Stockholmia Förlag, 1996.

Yttergren, Leif och Hans Bolling. "Kvinnor, karriär och familj. En studie av svenska kvinnliga gymnastikdirektörers yrkeskarriärer och livsöden kring sekelskiftet 1900." Historisk tidskrift 136, no. 2 (2016).

\section{Internet}

Statistiska centralbyrån. http://www.statistikdatabasen.scb.se/pxweb/sv/ssd/START_ BE_BE0101_BE0101I/Medellivslangd/table/tableViewLayout1.

Stockholm stad. Statistik om Stockholm: http://statistik.stockholm.se/images/stories/ pdf/Historisk_befolkning_web.pdf. 